\title{
Properties of genes involved in the control of isocitrate lyase production in Aspergillus nidulans
}

\author{
W. McCullough* and A. Shanks \\ Department of Biological and Biomedical Sciences, University of Ulster at Jordanstown, Jordanstown, \\ Co. Antrim BT37 OQB, Northern Ireland, UK
}

(Received 13 October 1992; revised 1 December 1992; accepted 4 December 1992)

\begin{abstract}
The interaction between genes of $A$ spergillus nidulans conferring constitutive synthesis of isocitrate lyase (icl $\boldsymbol{A}$ and $\left.i{ }^{c} B\right)$ and fluoroacetate resistance $(f a c B)$ has been investigated. Although $f a c B$ mutants are unable to induce the glyoxylate cycle enzyme isocitrate lyase in response to acetate as sole carbon source, this phenotype was suppressed in recombinants of the type $i \mathrm{icl}^{c} ; \mathrm{facB}$. The $i c l^{c} A$ and $i c l^{c} B$ mutations do not alter significantly the activities of eight enzymes of intermediary metabolism assayed. We conclude that the $i^{c}{ }^{c}$ genes are probably bona fide isocitrate lyase regulatory genes.
\end{abstract}

\section{Introduction}

The enzymes of the glyoxylate cycle, isocitrate lyase and malate synthase, are induced in the filamentous fungus Aspergillus nidulans in response to acetate as sole carbon source (Armitt et al., 1976). The structural genes for the enzymes have been characterized; $a c u D$ is the gene for isocitrate lyase (Armitt et al., 1970) and $a c u E$ is the gene for malate synthase (Armitt et al., 1971). Genes have also been identified which give either an uninducible or constitutive phenotype. The gene $f a c B$, which confers fluoroacetate resistance (Apirion, 1965), has been proposed as a positive regulatory gene required for the induction of those enzymes involved in the metabolism of acetamide and acetate (Katz \& Hynes, 1989). Other mutants which make isocitrate lyase constitutively have been isolated through reversion of a pyruvatecarboxylase-less strain by analogy with E. coli (Brice \& Kornberg, 1968), and also under non-selective conditions by screening colonies growing on sucrose agar medium. These mutants (McCullough \& Roberts, 1980) map at two unlinked loci, $i \mathrm{cl}^{c} A$ and $i c l^{c} B$ and contain low constitutive activity (about $10 \%$ of the fully induced wild-type). The $i c l^{c} A$ and $i c l^{c} B$ mutations in the double mutant $\left(\right.$ icl $\left.^{c} A 4 ; i^{c} l^{c} B 1\right)$ have constitutive activity which is $40 \%$ of the fully induced wild-type.

Doubts have been expressed about the nature of the $i c l^{c}$ genes and their role in the genetic control of isocitrate lyase (McCullough \& Roberts, 1980; McCullough et al.,

*Author for correspondence. Tel. (0232) 365131; fax (0232) 362808 .
1986). It was suggested that the defects might be in structural genes encoding enzymes of intermediary metabolism in such a way as to cause spurious increases in the concentration of the (unknown) inducer of isocitrate lyase activity. This interpretation seems unlikely (unless a fully constitutive phenotype is lethal), since mutations at both loci were recovered in a screening programme which did not select for a phenotype other than constitutive gene expression (McCullough \& Roberts, 1980). This paper reports a survey of other related enzymes in the $i c l^{c}$ mutants which might indicate metabolic disturbances. We also report on the interaction between the $i c{ }^{c}$ genes and $f a c B$.

\section{Methods}

Growth media. A. nidulans was grown in liquid minimal medium as described previously (Armitt et al., 1976), except that filter-sterilized $1 \mathrm{M}$-urea (rather than nitrate) was added as a nitrogen source to a final concentration of $5 \mathrm{~mm}$. For growth tests, the same medium solidified with agar was used. The carbon sources were sucrose and acetate to $20 \mathrm{~mm}$ and $100 \mathrm{~mm}$ respectively, and nutritional supplements were added as required to the sterilized medium.

Enzyme assays. Mycelia for enzyme assays were harvested by

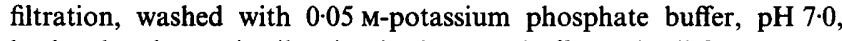
broken by ultrasonic vibration in the same buffer and cell-free extracts recovered as the clarified supernatants after centrifugation for $20 \mathrm{~min}$ at $15000 \mathrm{~g}$ and $4{ }^{\circ} \mathrm{C}$. Enzymes were assayed essentially by published procedures as follows: acetyl-CoA synthase (Jones \& Lipmann, 1955); isocitrate lyase (Armitt et al., 1970); malate synthase (Armitt et al., 1971); citrate synthase (Cooper \& Beevers, 1969), NADP ${ }^{+}$-dependent isocitrate dehydrogenase (Kornberg, 1955); succinate dehydrogenase (Ellis, 1959); fumarase (Hill \& Bradshaw, 1969); malate dehydrogenase (Khouw \& McCurdy, 1969); pyruvate kinase (McCullough \& Roberts, 1974); and ATP-citrate lyase as in Osmani \& Scrutton (1983). 
A. nidulans strains. The strains used were $\mathrm{R} 21$ ( $y A 2$ pabaA1), R153

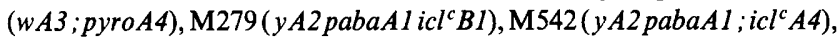
M545 (pyroA4 icl $^{c} A 4 ; i c l^{c} B I$ ) and M483 (facB101;biAl). The fluoroacetate-resistant mutant facB101 was isolated by Apirion (1965). Standard techniques were used for setting up and analysing Aspergillus crosses (Pontecorvo et al., 1953; Clutterbuck, 1984).

\section{Results and Discussion}

Table 1 shows the results from experiments in which a selection of enzyme activities were measured in $A$. nidulans strain $\mathrm{R} 21$ and the constitutive strains after growth under non-inducing conditions. It is clear that

Table 1. Enzyme activities in the wild-type and isocitrate-lyase-constitutive mutants after growth under non-inducing conditions

The activities of the enzymes were assayed in cell-free extracts prepared from mycelia grown in sucrose minimal medium. Each enzyme assay was repeated three times with close agreement between replicates.

\begin{tabular}{|c|c|c|c|c|}
\hline \multirow[b]{2}{*}{ Enzyme } & \multicolumn{4}{|c|}{ Activity $\left[\mu \mathrm{mol} \mathrm{h}^{-1}(\mathrm{mg} \text { protein })^{-1}\right]$ in } \\
\hline & $\begin{array}{l}\text { Wild- } \\
\text { type }\end{array}$ & $i c l^{c} A$ & $i^{c} l^{c} B$ & $i c l^{2} A ; i c l^{c} B$ \\
\hline Aconitase & $4 \cdot 5$ & $4 \cdot 3$ & $3 \cdot 0$ & $3 \cdot 3$ \\
\hline Fumarase & $33 \cdot 8$ & $29 \cdot 8$ & $28 \cdot 2$ & $39 \cdot 3$ \\
\hline $\begin{array}{l}\text { Malate dehydrogenase } \\
(\times 100)\end{array}$ & $10 \cdot 0$ & $7 \cdot 3$ & $10 \cdot 4$ & $8 \cdot 8$ \\
\hline $\begin{array}{l}\mathrm{NADP}^{+} \text {-dependent } \\
\text { isocitrate dehydrogenase }\end{array}$ & $8 \cdot 2$ & $7 \cdot 8$ & $7 \cdot 6$ & $8 \cdot 2$ \\
\hline Succinate dehydrogenase & 0.6 & $1 \cdot 1$ & 0.9 & $1 \cdot 3$ \\
\hline Pyruvate kinase & $42 \cdot 4$ & $37 \cdot 7$ & 56 & 48 \\
\hline Citrate synthase & $23 \cdot 2$ & $28 \cdot 6$ & $22 \cdot 4$ & $19 \cdot 3$ \\
\hline ATP-citrate lyase & $14 \cdot 3$ & $11 \cdot 3$ & $10 \cdot 9$ & $12 \cdot 5$ \\
\hline
\end{tabular}

Table 2. Isocitrate lyase activities in mycelia of isocitrate-lyase-constitutive strains $\left(\right.$ icl $\left.^{c}\right)$ after growth under non-inducing conditions with sucrose as sole carbon source

Isocitrate lyase activity was measured in cell-free extracts of mycelium from the wild-type and constitutive mutants grown on sucrose or acetate medium. The growth conditions and media have been described previously (McCullough \& Roberts, 1980).

\begin{tabular}{lcc}
\hline \hline Genotype & Carbon source & $\begin{array}{c}\text { Isocitrate lyase activity } \\
{\left[\mu \mathrm{mol} \text { glyoxylate } \mathrm{h}^{-1}\right.} \\
\left.(\mathrm{mg} \text { protein })^{-1}\right]\end{array}$ \\
\hline Wild-type & Acetate & 35 \\
Wild-type & Sucrose & $<0 \cdot 1$ \\
$\mathrm{facB}_{i c l^{a} A}$ & Sucrose & $<0 \cdot 1$ \\
$i c l^{c} B$ & Sucrose & $4 \cdot 61$ \\
$i c l^{B} A ; f a c B$ & Sucrose & $2 \cdot 13$ \\
$i c l^{C} B ; f a c B$ & Sucrose & $4 \cdot 23$ \\
$i c l^{c} A ; i c l^{c} B$ & Sucrose & $2 \cdot 63$ \\
$i c l^{c} A ; i c l^{c} B ; f a c B$ & Sucrose & 7.07 \\
\hline \hline
\end{tabular}

none of the enzyme activities differ significantly from the wild-type grown on sucrose medium. In particular, there is no change in $\mathrm{NADP}^{+}$-dependent isocitrate dehydrogenase, which is known to increase in activity in response to acetate (McCullough et al., 1977). It is known from a previous study (McCullough \& Roberts, 1980) that two other enzymes of acetate metabolism, acetyl-CoA synthase and malate synthase, are similarly not induced or derepressed in the $i c l^{c}$ mutants after growth under noninducing conditions.

Therefore, the $i \mathrm{cl}^{c}$ mutations appear to act specifically on the gene for isocitrate lyase. This contrasts with the situation in E. coli where the genes for the two glyoxylate cycle enzymes constitute an operon and are both produced constitutively in ace $R$ mutants (Brice \& Kornberg, 1968). In A. nidulans, the genes for the two enzymes are on different chromosomes, and although the genes for acetyl-CoA synthase and isocitrate lyase are tightly linked $(<1 \mathrm{cM})$ (Armitt et al., 1976), they are separated by at least $30 \mathrm{~kb}$ of DNA sequence (G. Turner, personal communication).

It has been proposed that the fluoroacetate-resistance gene, facB (Apirion, 1965), encodes a positive-acting regulatory protein required for the induction of acetamidase (amdS) and the three major acetate-specific enzymes acetyl-CoA synthase, isocitrate lyase and malate synthase (Hynes, 1977). Analysis of 'upstream' sequences and cis-acting mutations in amdS have identified the binding site for the $f a c B$ protein (Hynes et al., 1988). However comparable evidence at a molecular level that $f a c B$ regulates the other genes of acetate metabolism is lacking. Indeed, the $f a c B$ protein appears to play a structural role since two temperature-sensitive $f a c B$ alleles cause thermolability of acetyl-CoA synthase, isocitrate lyase and malate synthase (Hynes et al., 1988).

We have sought to investigate further the relative roles of $i l^{c}$ and $f a c B$ by combining the mutant genes. When strains carrying either of the $i c l^{c}$ genes were crossed with a strain carrying $f a c B$, there were four classes of progeny with respect to fluoroacetate resistance and isocitrate lyase constitutivity, present in approximately equal numbers (data not shown). In each case, one class gave a fluoroacetate-resistant, isocitrate-lyase-constitutive phenotype and had the expected genotype $\left(\mathrm{facB} ; \mathrm{icl}^{c}\right)$ confirmed in backcrosses. This demonstrates that the $i^{c} l^{c}$ alleles are epistatic to the $f a c B$ gene. Double mutant recombinants $\left(f a c B ; i c l^{c}\right)$ and the triple mutant strain $\left(\mathrm{facB} ; \mathrm{icl}^{c} A ; i \mathrm{icl} B\right)$ were constructed in a series of crosses and isocitrate lyase activity was measured in mycelium after growth in sucrose medium. The results are shown in Table 2. It can be seen that the $f a c B$ mutation does not reduce or abolish the isocitrate-lyase-constitutive phenotype in the single or double mutant constitutive strains. Clearly, the $i c l^{c}$ gene products must function upstream of 
the $f a c B$ product, although the molecular mechanism remains obscure.

It is very likely that a number of regulatory genes are involved in the control of the genes for the glyoxylate cycle enzymes, because of the central role and strategic importance of the cycle in metabolism and the location of the enzymes within the glyoxysomes. The results presented here support the premise (McCullough \& Roberts, 1980) that the $\mathrm{icl}^{c}$ genes are elements in the control system, although the precise roles of these genes have not yet been defined. We are currently attempting to clone and sequence the $i \mathrm{cl}^{c}$ genes to gain further information on the structure and likely functions of the gene products.

We thank the Department of Education (N. I.) for the award of a postgraduate studentship to A.S. We also thank Mr Roy Crowe and Mr Robin Ritchie for technical support.

\section{References}

APIRION, D. (1965). The two-way selection of mutants and revertants in respect of acetate utilisation and resistance to fluoroacetate in Aspergillus nidulans. Genetical Research 6, 317-329.

Armitt, S., Roberts, C. F. \& Kornberg, H. L. (1970). The role of isocitrate lyase in Aspergillus nidulans. FEBS Letters 7, 231-234.

ARMiTT, S., RoberTs, C. F. \& KorNBERG, H. L. (1971). Mutants of Aspergillus nidulans lacking malate synthase. FEBS Letters 12, 276-278.

Armitt, S., McCullough, W. \& RoberTs, C. F. (1976). Analysis of acetate non-utilizing mutants in Aspergillus nidulans. Journal of General Microbiology 92, 263-282.

BRICE, C. B. \& KORNBERG, H. L. (1968). Genetic control of isocitrate lyase in Escherichia coli. Journal of Bacteriology 96, 2185-2186.

ClutterbuCK, A. J. (1984). Loci and linkage map of the filamentous fungus Aspergillus nidulans. In Genetic Maps, 3, pp. 265-273. Edited by S. J. O'Brien. Cold Spring Harbor, NY: Cold Spring Harbor Laboratory.
COOPER, T. G. \& BEEVERs, H. (1969). Mitochondria and glyoxysomes from castor bean endosperm. Journal of Biological Chemistry 244, $3507-3513$.

ElLIS, H. A. (1959). A colorimetric method for the assay of soluble succinic dehydrogenase and pyridine nucleotide-linked dehydrogenases. Archives of Biochemistry and Biophysics 85, 561-562.

Hill, R. L. \& Bradshaw, R. A. (1969). Fumarase. Methods in Enzymology 13, 91-99.

HYNES, M. J. (1977). Induction of the acetamidase of Aspergillus nidulans by acetate metabolism. Journal of Bacteriology 131, 770-775.

Hynes, M. J., Corrick, C. M., Kelly, J. M. \& Littlejohn, T. G. (1988). Identification of the sites of action for regulatory genes controlling the amdS gene of Aspergillus nidulans. Molecular and Cell Biology 8, 2589-2596.

Jones, M. J. \& Lipmann, F. (1955). Aceto-CoA-kinase. Methods in Enzymology 1, 585-591.

KATZ, M. E. \& HYNES, M. J. (1989). Isolation and analysis of the acetate regulatory gene $f a c B$ from Aspergillus nidulans. Molecular and Cell Biology 9, 5696-5701.

Khouw, B. T. \& MCCuRDY, H. D. (1969). Tricarboxylic acid cycle enzymes and morphogenesis in Blastocladiella emersonii. Journal of Bacteriology 99, 197-205.

KoRNBERG, A. (1955). Isocitrate dehydrogenase of yeast. Methods in Enzymology 1, 705-707.

MCCUllough, W. \& RoberTs, C. F. (1974). The role of malic enzyme in Aspergillus nidulans. FEBS Letters 41, 238-242.

McCullough, W. \& RoBerts, C. F. (1980). The genetic control of isocitrate lyase in Aspergillus nidulans. Journal of General Microbiology 120, 67-84.

McCullough, W., Payton, M. A. \& Roberts, C. F. (1977). Carbon metabolism in Aspergillus nidulans. In Genetics and Physiology of Aspergillus, pp. 97-129. Edited by J. A. Smith \& J. A. Pateman. London \& New York: Academic Press.

McCullough, W., Roberts, C. F., Osmani, S. A. \& SCrutton, M. C. (1986). Regulation of carbon metabolism in filamentous fungi. In Carbohydrate Metabolism in Cultured Cells, pp. 287-355. Edited by M. J. Morgan. New York: Plenum Press.

Osmani, S. A. \& SCRutTon, M. C. (1983). The sub-cellular localisation of pyruvate carboxylase and some other enzymes in Aspergillus ndulans. European Journal of Biochemistry 147, 119-128.

Pontecorvo, G., Roper, J. A., Hemmons, L. M., MacDonald, K. D. \& Bufton, A. W. J. (1953). The genetics of Aspergillus nidulans. Advances in Genetics 5, 141-238. 